\title{
Invertebrates assemblage captured by a pink shrimp's fishery on Amazon continental shelf
}

\author{
Priscila Sousa Vilela da Nóbrega $a^{1}\left(\mathbb{D}\right.$, Cléverson Ranniéri Meira dos Santos ${ }^{2}$ \\ Ana Patrícia Barros Cordeiro ${ }^{3}$ \& $\&$ Jussara Moretto Martinelli-Lemos ${ }^{1} \mathbb{C}$ \\ ${ }^{1}$ Aquatic Ecology and Amazon Fisheries Nucleus, Federal University of Pará, Belém, PA, Brazil \\ ${ }^{2}$ Museu Paraense Emílio Goeldi, Belém, PA, Brazil \\ ${ }^{3}$ Amazon University, Coqueiro, PA, Brazil \\ Corresponding author: Priscila Sousa Vilela da Nóbrega (priscilasvnobrega@gmail.com)
}

\begin{abstract}
Shrimp trawl fisheries constitute a major threat to continental shelves' biodiversity, given their profound impact on benthic communities. We investigated the composition of an invertebrate assemblage impacted by this type of fishery and possible correlations of the abundance and richness with specific environmental parameters. The activities of the industrial shrimp fleet on the north coast of Brazil were monitored over two years. We analyzed 20,303 specimens belonging to seven phyla (Porifera, Cnidaria, Mollusca, Sipuncula, Annelida, Arthropoda, Echinodermata) and 154 species. There was a predominance of generalist and rare species, given that most species (86) were sporadic. Taxonomic composition patterns were complex, dynamic, and were correlated mainly with the temperature and depth of the Amazon continental shelf, the largest in extension and low depth of the South Atlantic. The crustaceans were dominant in both abundance and taxonomic richness. The influence of environmental factors on the abundance of the main species is discussed. The invertebrates are a neglected component in studies of fisheries impact and important components of the ecological structure of the Amazon coast. They are an essential group for developing a holistic fisheries management approach, which will support the sustainability of the region's fisheries and preserve local aquatic communities.
\end{abstract}

Keywords: Farfantepenaeus subtilis; shrimp trawl; bycatch; taxonomic composition; benthos; environmental factors

\section{INTRODUCTION}

The animals rejected by the shrimp trawling fisheries, the bycatch of these operations, constitute one of the most chronic ecological problems of continental shelves. In tropical regions, the reduced selectivity of the nets combined with these regions' high biological diversity results in capturing a much larger proportion of bycatch than the target species itself (Zeller \& Pauly 2005). Impacts from trawl fisheries may be modified significantly by the patterns of abundance, taxonomic richness, species dominance, and species dominance trophic structure (Fulton et al. 2005). The most preoccupying consequence of this scenario is the loss of biological and functional diversity, given the weakening of ecosystem structure and reducing its services (Buhl-Mortensen et al. 2016).
The bycatch's invertebrate component is frequently overlooked, not only by scientists but also by fishery managers and conservationists, due to a lack of emblematic species or an inadequate understanding of these organisms vulnerability (Guerra et al. 2011). The invertebrate diversity has been decreasing steadily since the 1960s (Philippart 1998) around the world, when trawling operations began, highlighting the negative effects of this activity, and its broad impacts, including a large part of the benthic community (Frid et al. 2000).

On the Amazon continental shelf, benthic invertebrates' biological activity, together with that of fish and mixotrophic animals, contributes to constructing carbonated structures that form the region's recentlydiscovered coral reefs (Moura et al. 2016). Fragments of invertebrates are an integral part of the rhodolite beds, 
in particular in the northwest of the shelf, and in many cases, small animals, such as annelids, ophiuroids, and mollusks, are found in the holes in these structures (Vale et al. 2018). Larger animals, such as crustaceans, echinoderms, and fish, together with wave action, also contribute to the rhodolite beds' morphology and mobility (Vale et al. 2018).

The benthic invertebrates are closely dependent on abiotic variables, which can interfere with the animals' physiological performance and reproductive success, which respond to this variation through either an increase or decrease in abundance, shifts in the distribution, or the taxonomic composition (Harley et al. 2006). Determining which patterns of the taxonomic organization reflect over-exploited environments and, in particular, those at risk of the loss of ecological function may contribute to the development of more effective species monitoring practices and conservation measures.

The massive discharge of this river forms the Amazon plume, a mass of low saline water that extends into the Atlantic Ocean off the north coast of Brazil, varying in extension and disposition over the year. The North Brazil Current and wind influence the circulation of these waters, regulating the plume's dispersal, direction, and velocity (Molleri et al. 2010). The rainy season in this region typically lasts from December to June, while the second half of the year (July to November) is considered the dry or less rainy season.

Although the knowledge of the bycatch on the north coast already exists, studies are limited to information on the occurrence of species (Cutrim et al. 2001, Aragão et al. 2015, Cintra et al. 2017), few works addressing the structure and spatial-temporal distribution of invertebrates along with the platform. Such studies lack ecological refining that allows inferring biological patterns that could be inserted in conservation and management policies. In this context, the present study investigated the structure of the invertebrates assemblage that are impacted by the shrimp fisheries of the north coast of Brazil and determining possible correlations of the abundance and richness with temperature substrates, salinity, and depth.

\section{MATERIALS AND METHODS}

\section{Study region}

The study region encompasses the Amazon continental shelf (ACS), which extends from the mouth of the Pará River north to Cape Orange, at the northern extreme of the Brazilian state of Amapá. The study area is located between $0.8-4.7^{\circ} \mathrm{N}$ and $47.85-51.17^{\circ} \mathrm{W}$ (Fig. 1). This area is influenced directly by the discharge of the Amazon River, which has the largest freshwater discharge of any body of water on the planet, and the principal outflow of the freshwater of the Amazon region (Masson \& Delecluse 2001).

Given the scale of the study area, the fishery operation zone was divided into four sub-regions, two located in the northern portion of the zone (NA: 4.7$3.7^{\circ} \mathrm{N}$, and NB: $3.8-2.8^{\circ} \mathrm{N}$ ), and two in the southern portion (SC: $1.8-2.7^{\circ} \mathrm{N}$, and SD: $1.7-0.8^{\circ} \mathrm{N}$ ) (Fig. 1). The two northern sub-regions are influenced more intensively and constantly by the Amazon plume, while the two southern sub-regions are influenced directly by the discharge of the Amazon River and are more subject to the seasonal variation in the characteristics of the plume. The sub-regions were divided equidistantly and with equal sampling effort in terms of the extent and hours of trawling. The shrimping ground name at which each sample was obtained was also recorded, based on the information provided by the master of the vessel.

\section{Field and laboratory procedures}

The samples were collected during the operations of the industrial shrimp fleet of the north coast of Brazil, which is composed of medium-sized boats with doublerig bottom trawls of $18.0 \times 22.4 \times 1.2 \mathrm{~m}$ and a mesh of $30 \times 21 \mathrm{~mm}$ and $20 \times 20 \mathrm{~mm}$ in the cod end. A total of 169 trawls were monitored, over $887.54 \mathrm{~h}$, between July 2015 and May 2017, bimonthly. According to the migration of adults of the target species, the operational area of the fleet shifts over the year, with the lower latitudes being focused on during the first few months of the year and operations shifting to the northwest as the year progresses, according to the migration of adults of the target species the pink shrimp Farfantepenaeus subtilis. This displacement obeys resource utilization's logic since the pink shrimp uses the mangroves of the Brazilian north coast to grow juveniles and adults migrate towards Guyana, following the south equatorial current the largest specimens of the species. Thus, the boats drag practically in a straight northwest direction, following the adult stock's migration.

The invertebrates found in the bycatch were collected from the net by an onboard sampler and immediately deposited on the vessel's deck, where they were placed in two $30 \mathrm{~kg}$ baskets. These samples remained frozen until processed in the laboratory, where they were identified to the lowest possible taxonomic level. For this study, we defined bycatch as all animals that were not destined for sale, including the target species, F. subtilis, when rejected due to the shrimp's small size.

The abiotic factors temperature, salinity, and depth of the water were measured through samples obtained at the moment of collection. The temperature was mea- 


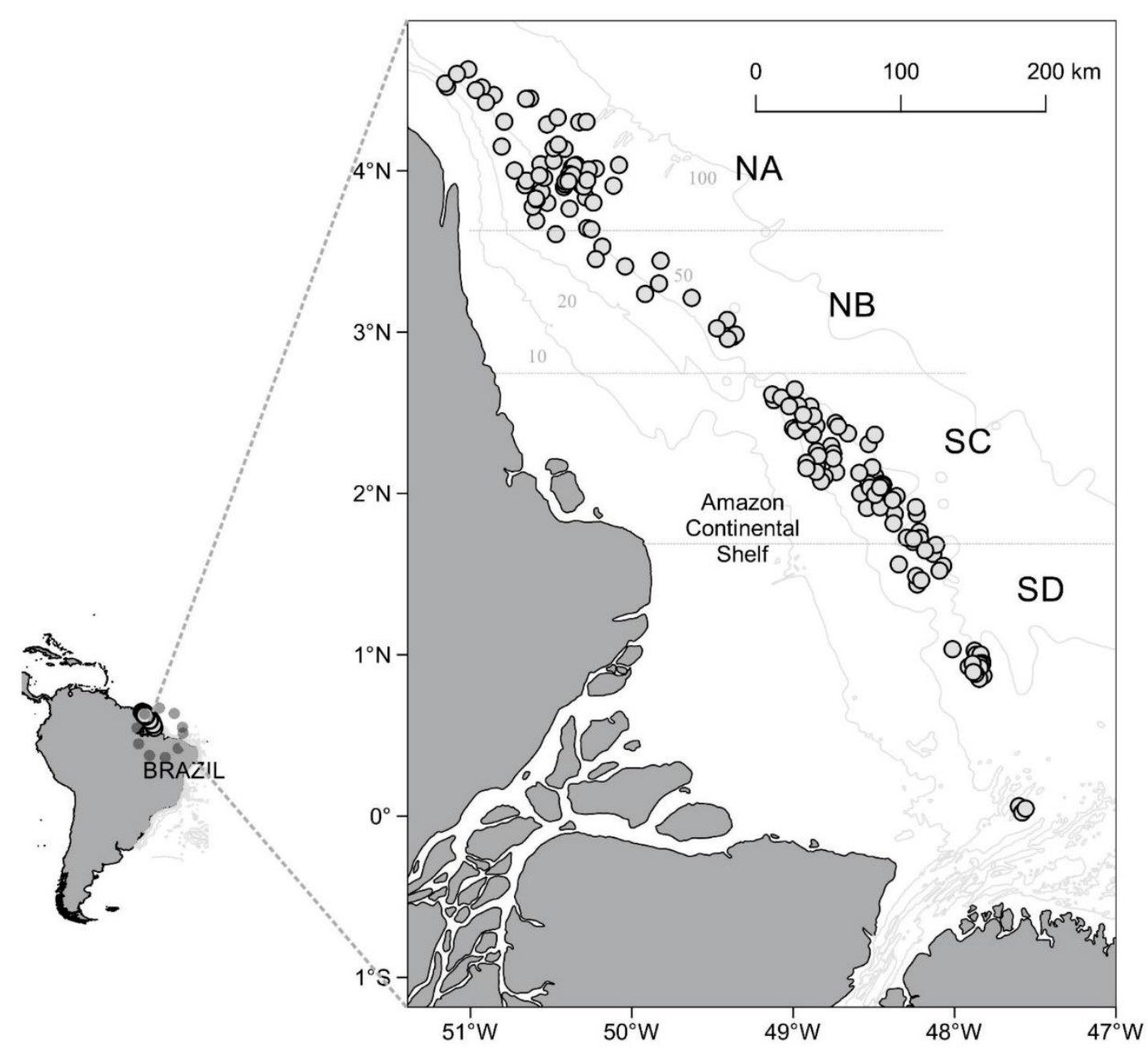

Figure 1. Points at which the invertebrate bycatch of the north coast of Brazil's industrial shrimp fleet was sampled between July 2015 and May 2017. NA: $4.7-3.7^{\circ} \mathrm{N}, \mathrm{NB}: 3.8-2.8^{\circ} \mathrm{N}, \mathrm{SC}: 1.8-2.7^{\circ} \mathrm{N}$, and SD: $1.7-0.8^{\circ} \mathrm{N}$.

sured with a mercury thermometer, salinity with an optical refractometer, and the vessel's depth sounder. The substrate was classified according to Nittrouer et al. (1986), who defined three principal categories for the study region: i) mottled mud, ii) mud intercalated with sand, and iii) partially laminated mud.

\section{Analysis of the data}

To identify the similarity of environmental factors (temperature, salinity, $\mathrm{pH}$, and substrate) of the shrimping ground it was used a hierarchical Cluster analysis, based on the Ward method and Euclidian distance, was run in the Past 3.20.

Relative abundance (RA) of each species was calculated by dividing the total number of individuals of each species by the total number of individuals captured in all the trawls. We established three abundance categories: i) very abundant (Va), when the species represented more than $5 \%$ of the individuals captured in all the trawls, ii) abundant (Ab), when the species contributed $1-5 \%$ of the individuals captured, and iii) rare $(\mathrm{Ra})$ when the species represented less than $1 \%$ of the individuals captured (Graça-Lopes et al. 1993).

To understand predictors of species richness, we defined a series of GLM (generalized linear model) that was adjusted to the data (McCullagh \& Nelder 1989), including all the principal effects, based on:

$$
\begin{gathered}
\eta_{\text {abcdehijk }}=\beta_{0}+\beta_{1 a}+\beta_{2 b}+\beta_{3 c}+\beta_{4 d}+\beta_{5 e} \\
+\beta_{6} p_{h}+\beta_{7} t_{i}+\beta_{8} s_{j}+\beta_{9} w_{k},
\end{gathered}
$$

where $\eta_{a b c d e f g h i j k}=g\left(E Y_{a b c d e h i j k}\right)$ is the linear predictor of the value number of species $\left(E Y_{a b c d e h i j k}\right)$ in the -th phase of the moon $(a=\{1,2,3,4\})$, in the -th region $(b=\{1,2,4,5\})$, in the -th substrate ( $c=$ $\{1,2,3,4,5\})$, in the -th bimester $(d=\{1,2, \ldots, 9\})$ of the -th year $(e=\{1,2,3\})$, with depth $p_{h}$, temperature $t_{i}$, 
salinity $s_{-} j$ and sampling effort $w_{k}$. The covariables with indices of $a$ to $e$ were considered qualitative, while those with $h$ to $k$ were treated as quantitative covariables.

Given the possibility of overdispersal, a common problem with count data (Hinde \& Demétrio 1998), two random components were considered for the distribution of $Y_{a b c d e f g h i j k}$ a Poisson distribution and a negative binomial distribution. In both cases, the logarithmic link function was applied, i.e. $\mathrm{g}(\cdot)=\ln (\cdot)$.

The covariates were then selected in a stepwise fashion from the adjustments of Equation (1) models and tests of likelihood rates. The final Poisson and negative binomial models were submitted to an analysis of residuals and diagnostics, particularly quantilequantile plots with simulated envelopes (Flack \& Flores 1989). Following the covariates' selection for each component and identifying the best random component, multiple comparisons were applied to all possible pairs of contrasts between one-factor levels, based on the Tukey test. All these analyses were run in the R 3.5 environment (R Core Team 2017), in the 'hnp' (Moral et al. 2017), 'MASS' (Venables \& Ripley 2002), and 'multcomp' (Hothorn et al. 2008) packages.

A redundancy analysis (RDA) was then applied to identify which predictors (temporal, spatial, or environmental) best explain the distribution of the occurrence of the species (response variable). The variables temperature, salinity, and depth are continuous, while the substrate, area, and month are categorical. Only the 11 species with the greatest frequency of occurrence were included in the analysis due to the enormous discrepancies in the species abundance scale. Hellinger's transformation (Legendre 2008) was applied to the abundance matrix data to reduce the importance of the most abundant taxa, given that it is indifferent to the number of zeros. A permutational ANOVA with 999 permutations was used to determine the significance of this analysis, run in the R 3.5 platform (R Core Team 2017).

\section{RESULTS}

\section{Environmental variables}

The trawls' mean depth varied significantly among months, with deeper trawls recorded during the least rainy months (June to December) and shallower trawls during the rainy season (December to May). Depths of between $35 \mathrm{~m}$ (February 2016) and $85 \mathrm{~m}$ (September 2016) were recorded during the study, with an overall mean depth of $54.22 \pm 7.89 \mathrm{~m}$ (standard deviation).

Salinity was the only variable that presented range amplitude, from 10 to 36 (overall mean of $28.52 \pm$ 5.71 ), with the highest values being recorded during the second half of 2015 and 2016. The water was more saline in 2015 than in the other years (Fig. 2).

The environmental characteristics (temperature, salinity and sediments) of the shrimping grounds in the two sub-zones (northern and southern) are distinct (Fig. $3)$. One exception is the "Beiradão" $\left(4.42-4.50^{\circ} \mathrm{N}\right.$, $50.90-51.2^{\circ} \mathrm{W}$ ) which, despite being located in the northern sub-zone, was more similar to the grounds located in the southern portion of the shelf (see the dark gray area in the right half of the dendrogram).

\section{Biological variables}

We analyzed 20,303 specimens representing seven phyla (Annelida, Arthropoda, Cnidaria, Echinodermata, Mollusca, Porifera, Sipuncula), 67 families, and 154 species. Rare species were predominant, given that a majority (86) was sporadic and together contributed only $1 \%$ of total abundance, whereas the other 68 species contributed $99 \%$ of the total number of individuals captured as bycatch by the shrimp fleet of the Amazon continental shelf. The species with the greatest abundance $(23.0 \%$ of the total) was the crab Achelous rufiremus (Holthuis, 1959), followed by the shrimp species Rimapenaeus similis (Smith, 1885) with $18.7 \%$ of the total, and Xiphopenaeus kroyeri (Heller, 1862), which contributed with $10.9 \%$ of the bycatch. The subphylum Crustacea predominated in terms of both the number of individuals (17.5 or $86.4 \%)$ and species (67 or $43.5 \%$ ), followed by: Mollusca, with $1524(7.4 \%)$ individuals and 53 (35\%) species (Fig. 4). In the Mollusca phyla, the greatest abundance groups were the Ostrea sp. with $2.0 \%$ of the total, followed by Abra lioica (Dall, 1881), which contributed with $0.7 \%$ of the bycatch (Table 1). In the Cnidaria phylum, the greatest abundance was the Renillidae sp. 1 (3.89\%), followed by Chiropsalmus quadrumanus (F. Muller, 1859).

\section{Interaction between biological and environmental variables}

As the model with the negative random binomial component was better according to the residuals analysis (Fig. 5), all the statistical inferences of the GLM were based on this model. The estimates of the parameters of the final model selected by the analysis are presented in Table 2.

The lunar phase and sub-region were the most important qualitative descriptors for adjusting the model and the covariables' depth and temperature. Increasing temperature and depth are both associated with a reduction in the expected number of species. Similarly, the NB, SC, and SD sub-regions all presented a reduction in expected species richness, while richness increased between the waning crescent and new moon. 


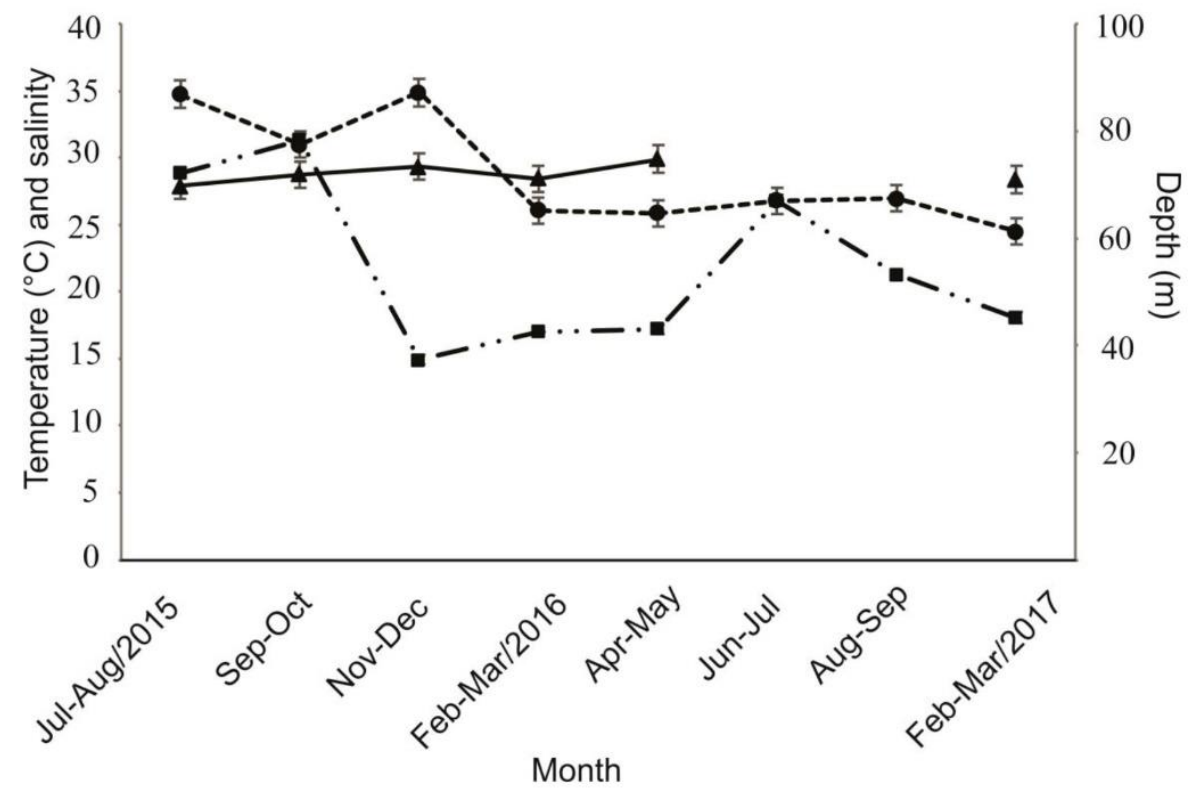

Figure 2. Mean depth $(\mathrm{m})$, salinity, and temperature $\left({ }^{\circ} \mathrm{C}\right)$ recorded on the Amazon continental shelf bimonthly of the study period. The vertical bars represent the standard deviation. Continuous line: temperature. Dashed line: salinity. Dashed and dotted line: depht.

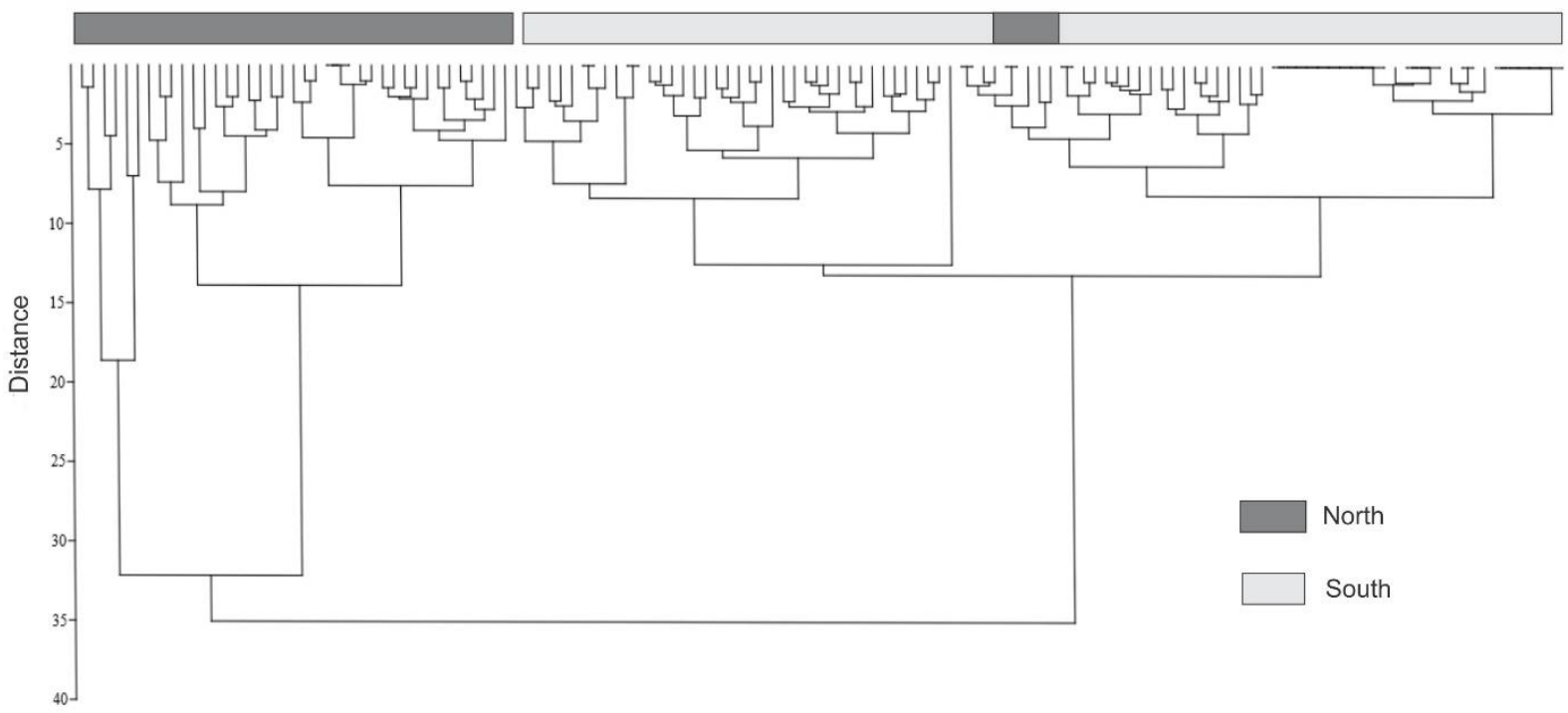

Figure 3. Dendrogram produced by the Cluster analysis of the shrimping grounds located in the northern and southern subzones of the Amazon continental shelf, based on their environmental characteristics. Cophenetic coefficient $=0.913$.

Significant differences were found in the expected number of species between the new and full moons and between the new and waning moons (Table 3). Given the positive estimates of the contrasts, also, it is possible to conclude that the expected number of species is greater during the new moon.

Significant variation was also found among the different sub-regions (Table 4), which formed two groups. One group was formed by the sub-regions NA and $\mathrm{NB}$, and the other by sub-regions SC and SD. The analyses indicate that greater species richness is expected in the northern sub-zone compared to the southern zone.

In the RDA, only the variables temperature and shrimping ground were correlated strongly $(>0.7)$ with abundance, both negatively (Fig. 6). The correlation coefficients obtained by the RDA are presented in Table 5 . The RDA explained approximately $25 \%$ of the data variability (adjusted R2: 24.7), with axis 1 being responsible for $55.2 \%$ of the variation, while axis 2 
Table 1. Invertebrate species are captured as bycatch by the industrial shrimp fleet operating on the Amazon continental shelf. n: number of individuals, RA: relative abundance, FR: frequency of occurrence (\%). Va: very abundant; Ab: abundant; Ra: rare.

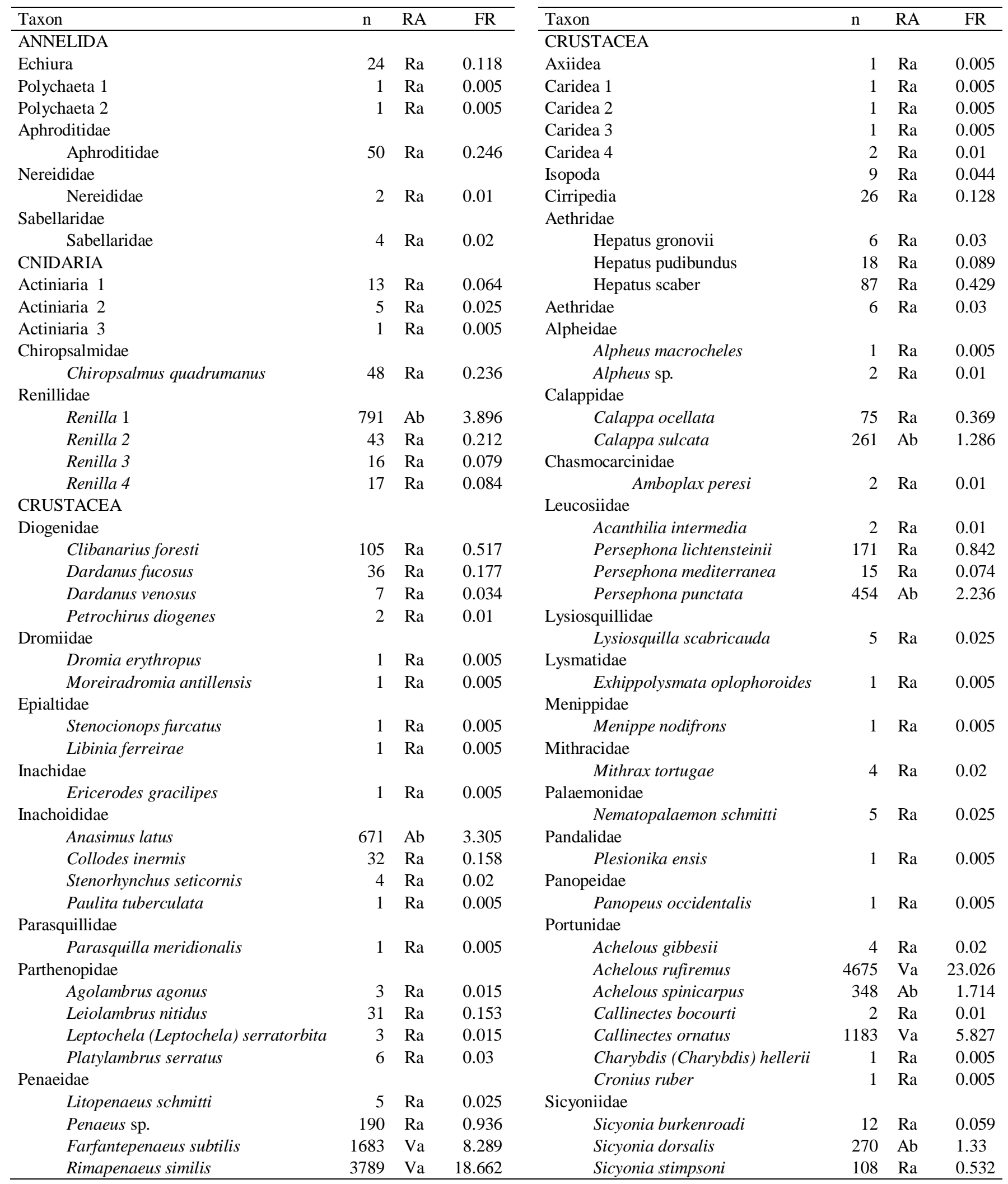


Continuation

\begin{tabular}{|c|c|c|c|c|c|c|c|}
\hline Taxon & $\mathrm{n}$ & RA & FR & Taxon & $\mathrm{n}$ & RA & FR \\
\hline Xiphopenaeus kroyeri & 2213 & $\mathrm{Va}$ & 10.9 & Sicyonia typica & 1 & $\mathrm{Ra}$ & 0.005 \\
\hline Pilumnidae & & & & Solenoceridae & & & \\
\hline Pilumnus diomedeae & 3 & $\mathrm{Ra}$ & 0.015 & Solenocera atlantidis & 7 & $\mathrm{Ra}$ & 0.034 \\
\hline Porcellanidae & & & & Solenocera geijskesi & 265 & $\mathrm{Ab}$ & 1.305 \\
\hline Porcellana sayana & 23 & $\mathrm{Ra}$ & 0.113 & Squillidae & & & \\
\hline ECHINODERMATA & & & & Squilla lijdingi & 696 & $\mathrm{Ab}$ & 3.428 \\
\hline Asteroidea 1 & 1 & $\mathrm{Ra}$ & 0.005 & MOLLUSCA & & & \\
\hline Asteroidea 2 & 41 & $\mathrm{Ra}$ & 0.202 & Bursidae & & & \\
\hline Asteroidea 3 & 9 & $\mathrm{Ra}$ & 0.044 & Marsupina bufo & 77 & $\mathrm{Ra}$ & 0.379 \\
\hline Asteroidea 4 & 3 & $\mathrm{Ra}$ & 0.015 & Calliostomatidae & & & \\
\hline Asteroidea 5 & 4 & $\mathrm{Ra}$ & 0.02 & Calliostoma sp. & 1 & $\mathrm{Ra}$ & 0.005 \\
\hline Asteroidea 6 & 26 & $\mathrm{Ra}$ & 0.128 & Calyptraeidae & & & \\
\hline Asteroidea 7 & 1 & $\mathrm{Ra}$ & 0.005 & Crepidula intratesta & 19 & $\mathrm{Ra}$ & 0.094 \\
\hline Asteroidea 8 & 12 & $\mathrm{Ra}$ & 0.059 & Calyptraea centralis & 67 & $\mathrm{Ra}$ & 0.33 \\
\hline Ophiuroidea 1 & 97 & $\mathrm{Ra}$ & 0.478 & Cardiidae & & & \\
\hline Ophiuroidea 2 & 1 & $\mathrm{Ra}$ & 0.005 & Americardia media & 2 & $\mathrm{Ra}$ & 0.01 \\
\hline Echinoidea & 1 & $\mathrm{Ra}$ & 0.005 & Chamidae & & & \\
\hline Holothuroidea & 3 & $\mathrm{Ra}$ & 0.015 & Arcinella brasiliana & 1 & $\mathrm{Ra}$ & 0.005 \\
\hline Gorgonocephalidae & & & & Columbellidae & & & \\
\hline Gorgonocephalidae & 2 & $\mathrm{Ra}$ & 0.010 & Anachis catenata & 1 & $\mathrm{Ra}$ & 0.005 \\
\hline SIPUNCULA & & & & Conidae & & & \\
\hline Sipuncula & 8 & $\mathrm{Ra}$ & 0.039 & Conus sp. & 4 & $\mathrm{Ra}$ & 0.02 \\
\hline MOLLUSCA & & & & Corbulidae & & & \\
\hline Cymatiidae & & & & Caryocorbula swiftiana & 5 & $\mathrm{Ra}$ & 0.025 \\
\hline Monoplex parthenopeus & 1 & $\mathrm{Ra}$ & 0.005 & Crassatellidae & & & \\
\hline Dentaliidae & & & & Crassinella sp. & 55 & $\mathrm{Ra}$ & 0.271 \\
\hline Dentalium sp. & 1 & $\mathrm{Ra}$ & 0.005 & Nassariidae & & & \\
\hline Fasciolariidae & & & & Phrontis alba & 17 & $\mathrm{Ra}$ & 0.084 \\
\hline Aurantilaria aurantiaca & 1 & $\mathrm{Ra}$ & 0.005 & Phrontis vibex & 1 & $\mathrm{Ra}$ & 0.005 \\
\hline Fusinus helenae & 3 & $\mathrm{Ra}$ & 0.015 & Naticidae & & & \\
\hline Loliginidae & & & & Natica marochiensis & 4 & $\mathrm{Ra}$ & 0.02 \\
\hline Doryteuthis (Amerigo) pealeii & 127 & $\mathrm{Ra}$ & 0.626 & Stigmaulax cayennensis & 1 & $\mathrm{Ra}$ & 0.005 \\
\hline Lucinidae & & & & Sinum perspectivum & 2 & $\mathrm{Ra}$ & 0.01 \\
\hline Divalinga quadrisulcata & 1 & $\mathrm{Ra}$ & 0.005 & Nuculanidae & & & \\
\hline Margaritidae & & & & Saccella larranagai & 22 & $\mathrm{Ra}$ & 0.108 \\
\hline Pinctada imbricata & 1 & $\mathrm{Ra}$ & 0.005 & Octopodidae & & & \\
\hline Prunum storeria & 1 & $\mathrm{Ra}$ & 0.005 & Octopus insularis & 1 & $\mathrm{Ra}$ & 0.005 \\
\hline Muricidae & & & & Olividae & & & \\
\hline Stramonita brasiliensis & 3 & $\mathrm{Ra}$ & 0.015 & Americoliva circinata & 9 & $\mathrm{Ra}$ & 0.044 \\
\hline Chicoreus brevifrons & 12 & $\mathrm{Ra}$ & 0.059 & Olivella sp. & 3 & $\mathrm{Ra}$ & 0.015 \\
\hline Mytilidae & & & & Ostreidae & & & \\
\hline Modiolus americanus & 9 & $\mathrm{Ra}$ & 0.044 & Ostrea sp. 1 & 1 & $\mathrm{Ra}$ & 0.005 \\
\hline Musculus lateralis & 1 & $\mathrm{Ra}$ & 0.005 & Ostrea $\mathrm{sp} .2$ & 415 & $\mathrm{Ab}$ & 2.044 \\
\hline Personidae & & & & Pectinidae & & & \\
\hline Distorsio clathrata & 5 & $\mathrm{Ra}$ & 0.025 & Euvola chazaliei & 67 & $\mathrm{Ra}$ & 0.33 \\
\hline Pinnidae & & & & Euvola marensis & 30 & $\mathrm{Ra}$ & 0.148 \\
\hline Atrina seminuda & 7 & $\mathrm{Ra}$ & 0.034 & Turridae & & & \\
\hline Plicatulidae & & & & Polystira sp. & 18 & $\mathrm{Ra}$ & 0.089 \\
\hline Plicatula gibbosa & 4 & $\mathrm{Ra}$ & 0.02 & Veneridae & & & \\
\hline Pteriidae & & & & Tivela fulminata & 1 & $\mathrm{Ra}$ & 0.005 \\
\hline Pteria colymbus & 16 & $\mathrm{Ra}$ & 0.079 & Lirophora paphia & 1 & $\mathrm{Ra}$ & 0.005 \\
\hline Semelidae & & & & Pitar albidus & 42 & $\mathrm{Ra}$ & 0.207 \\
\hline Abra lioica & 150 & $\mathrm{Ra}$ & 0.739 & Verticordiidae & & & \\
\hline Tellinidae & & & & Haliris sp. & 1 & $\mathrm{Ra}$ & 0.005 \\
\hline Eurytellina trinitatis & 8 & $\mathrm{Ra}$ & 0.039 & Volutidae & & & \\
\hline
\end{tabular}


Continuation

\begin{tabular}{|c|c|c|c|c|c|c|c|}
\hline Taxon & $\mathrm{n}$ & RA & FR & Taxon & $\mathrm{n}$ & RA & FR \\
\hline Strigilla carnaria & 2 & $\mathrm{Ra}$ & 0.010 & Voluta ebraea & 1 & $\mathrm{Ra}$ & 0.005 \\
\hline Terebridae & & & & Yoldiidae & & & \\
\hline Terebra taurina & 2 & $\mathrm{Ra}$ & 0.010 & Adrana electa & 96 & $\mathrm{Ra}$ & 0.473 \\
\hline Tonnidae & & & & Adrana sp. & 67 & $\mathrm{Ra}$ & 0.33 \\
\hline Tonna galea & 112 & $\mathrm{Ra}$ & 0.552 & & & & \\
\hline \multicolumn{8}{|l|}{ Turbinellidae } \\
\hline Turbinella laevigata & 25 & $\mathrm{Ra}$ & 0.123 & & & & \\
\hline \multicolumn{8}{|l|}{ PORIFERA } \\
\hline Porifera 1 & 3 & $\mathrm{Ra}$ & 0.015 & & & & \\
\hline Porifera 2 & 1 & $\mathrm{Ra}$ & 0.005 & & & & \\
\hline \multicolumn{8}{|l|}{ Aplysinidae } \\
\hline Aplysina pseudolacunosa & 1 & $\mathrm{Ra}$ & 0.005 & & & & \\
\hline \multicolumn{8}{|l|}{ Irciniidae } \\
\hline Ircinia sp. & 1 & $\mathrm{Ra}$ & 0.005 & & & & \\
\hline \multicolumn{8}{|l|}{ Microcionidae } \\
\hline Clathria (Clathria) nicoleae & 3 & $\mathrm{Ra}$ & 0.015 & & & & \\
\hline
\end{tabular}

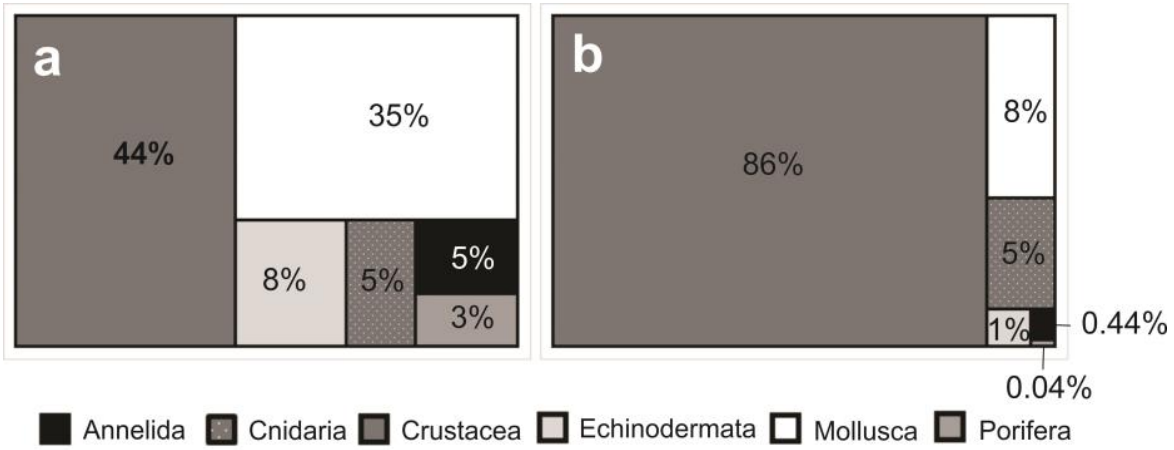

Figure 4. Relative frequency (\%) of the different taxonomic groups of invertebrates captured as bycatch on the Amazon continental shelf. a) Number of species, b) number of individuals.

explained $30.7 \%$. The first axis's negative orientation included temperature and salinity, although there was only a moderate association of Callinectes ornatus with temperature. By contrast, the crabs Persephona punctata and Anasimus latus were correlated positively with depth. The second axis's positive orientation was not associated with any species, whereas in the negative direction, the cnidarian Renilla sp. 1 and the shrimp $X$. kroyeri correlated with the type of substrate. The crab C. ornatus was also associated to a moderate degree with the shrimping ground. The most abundant invertebrate, A. rufiremus, was not correlated with any of the environmental variables. The RDA was significant at a 95\% confidence level (Table 6).

\section{DISCUSSION}

The invertebrate assemblage impacted by the shrimp fisheries on the ACS had high species richness, rare species predominance, and a high proportion of sporadic captures, which translate into a highly complex taxonomic composition. This taxonomic richness is sensitive to temperature changes, which requires further attention, given the current climate change scenario, and reinforces the need for the integrated analysis of biological, physical and chemical descriptors. Fisheries that generate a large diversity of bycatch are a challenge for stock management, given the need to identify priorities to make monitoring viable, based on the different species' susceptibility (Stobutzki et al. 2001).

Bottom trawling is known to provoke the loss of both biological and functional diversity, in particular specialists and ecologically sensitive species (Hall et al. 2000, Jimenes et al. 2016). The industrial fisheries from the Brazilian north coast have been operating continuously since the 1960 s, creating a high-impact scenario. Despite this, the regions' fauna is still enormously diverse, even compared with other tropical regions (Stobutzki et al. 2001, Tonks et al. 2008). This 

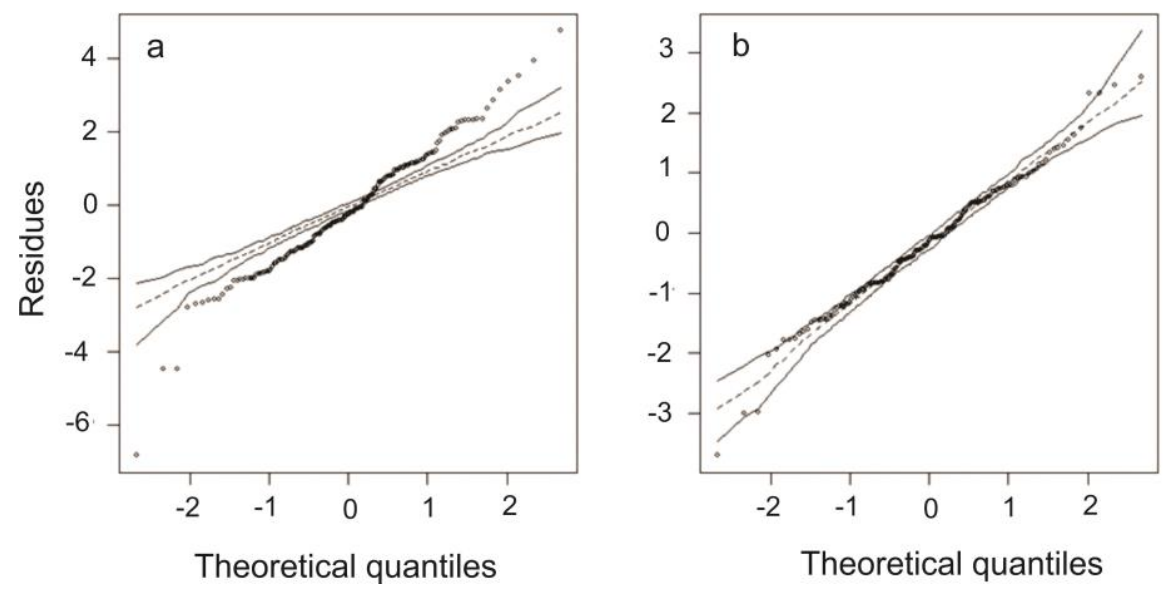

Figure 5. Normal quantile-quantile graphs with a simulated envelope of the adjusted models after covariate selection. a) Poisson random component, b) negative binomial random component.

Table 2. Estimates (and their respective standard errors) of the final model's parameters (random negative binomial component with logarithmic link function) selected for the species richness. $\beta_{12}$ : effect of the waning moon phase; $\beta_{13}$ : effect of the waxing moon phase; $\beta 14$ : effect of the new moon; $\beta_{22}$ : effect of sub-region NB; $\beta_{23}$ : effect of sub-region SC; $\beta_{24}$ : effect of sub-region SD; $\beta_{6}$ : effect of depth; $\beta_{7}$ : effect of temperature; $\kappa$ : parameter of overdispersal of the negative binomial distribution. Z: absolute value of Wald's statistic. *Significant values $(P<0.5)$.

\begin{tabular}{lrccc}
\hline Parameter & Estimate & Standard error & $\mathrm{Z}$ & $P$ \\
\hline Intercept & 11.536906 & 1.457536 & 7.915 & $<0.0001^{*}$ \\
$\beta_{12}$ & 0.087722 & 0.121077 & 0.725 & 0.469 \\
$\beta_{13}$ & 0.103086 & 0.144687 & 0.712 & 0.476 \\
$\beta_{14}$ & 0.468594 & 0.118704 & 3.948 & $<0.0001^{*}$ \\
$\beta_{22}$ & -0.176373 & 0.146583 & 1.203 & 0.229 \\
$\beta_{23}$ & -0.779851 & 0.187163 & 4.167 & $<0.0001^{*}$ \\
$\beta_{24}$ & -1.064609 & 0.145338 & 7.325 & $<0.0001^{*}$ \\
$\beta_{6}$ & -0.010157 & 0.003849 & 2.639 & 0.008 \\
$\beta_{7}$ & -0.291659 & 0.050843 & 5.736 & $<0.0001^{*}$ \\
$k$ & 5.0383 & - & - & - \\
\hline
\end{tabular}

Table 3. Contrasts (multiple comparisons) among the moon phases, based on the final model, adjusted to species richness data. Z: absolute value of Wald's statistic, *Significant values $(P<0.5)$.

\begin{tabular}{lcccc}
\hline Contrast & Estimate & Standard error & $\mathrm{Z}$ & $P$ \\
\hline Waning-full & 0.08772 & 0.12108 & 0.725 & 0.8861 \\
Waxing-full & 0.10309 & 0.14469 & 0.712 & 0.891 \\
New-full & 0.46859 & 0.1187 & 3.948 & $<0.001^{*}$ \\
Waxing-waning & 0.01536 & 0.15646 & 0.098 & 0.9997 \\
New-waning & 0.38087 & 0.13004 & 2.929 & 0.0176 \\
Waxing-new & 0.36551 & 0.14754 & 2.477 & 0.0624 \\
\hline
\end{tabular}

may be the result of the region's highly complex ecosystems, established through the association of the multiple features that are unique to the Amazon coast, in particular, its status as the largest freshwater drainage of the Atlantic Ocean, which creates physicochemical conditions on the continental shelf that include (i) the enormous sediment load of the Amazon River, which is deposited in distinct forms within the extension of the estuary, with the more internal and intermediate areas having significantly higher and more rapid rates of sedimentation (Nittrouer et al. 1986); (ii) differences in the intensity and frequency of the Amazon plume over the shelf, which is more constant in its northern portion and more seasonal in the south (Moura et al. 2016), 
Table 4. Contrasts (multiple comparisons) among the subregions, based on the final model, adjusted to species richness data. NA: $4.7-3.7^{\circ} \mathrm{N}, \mathrm{NB}: 3.8-2.8^{\circ} \mathrm{N}, \mathrm{SC}: 1.8-2.7^{\circ} \mathrm{N}$, and SD: $1.7-0.8^{\circ} \mathrm{N}$. Z: absolute value of Wald's statistic, *Significant values $(P<0.5)$.

\begin{tabular}{lcccc}
\hline Contrast & Estimate & Standard error & $\mathrm{Z}$ & $P$ \\
\hline NB-NA & -0.1764 & 0.1466 & 1.203 & 0.61672 \\
SC-NA & -0.7799 & 0.1872 & 4.167 & $<0.001^{*}$ \\
SD-NA & -1.0646 & 0.1453 & 7.325 & $<0.001^{*}$ \\
SC-NB & -0.6035 & 0.1906 & 3.166 & 0.00819 \\
SD-NB & -0.8882 & 0.1551 & 5.725 & $<0.001^{*}$ \\
SC-SD & -0.2848 & 0.1451 & 1.963 & 0.1964 \\
\hline
\end{tabular}

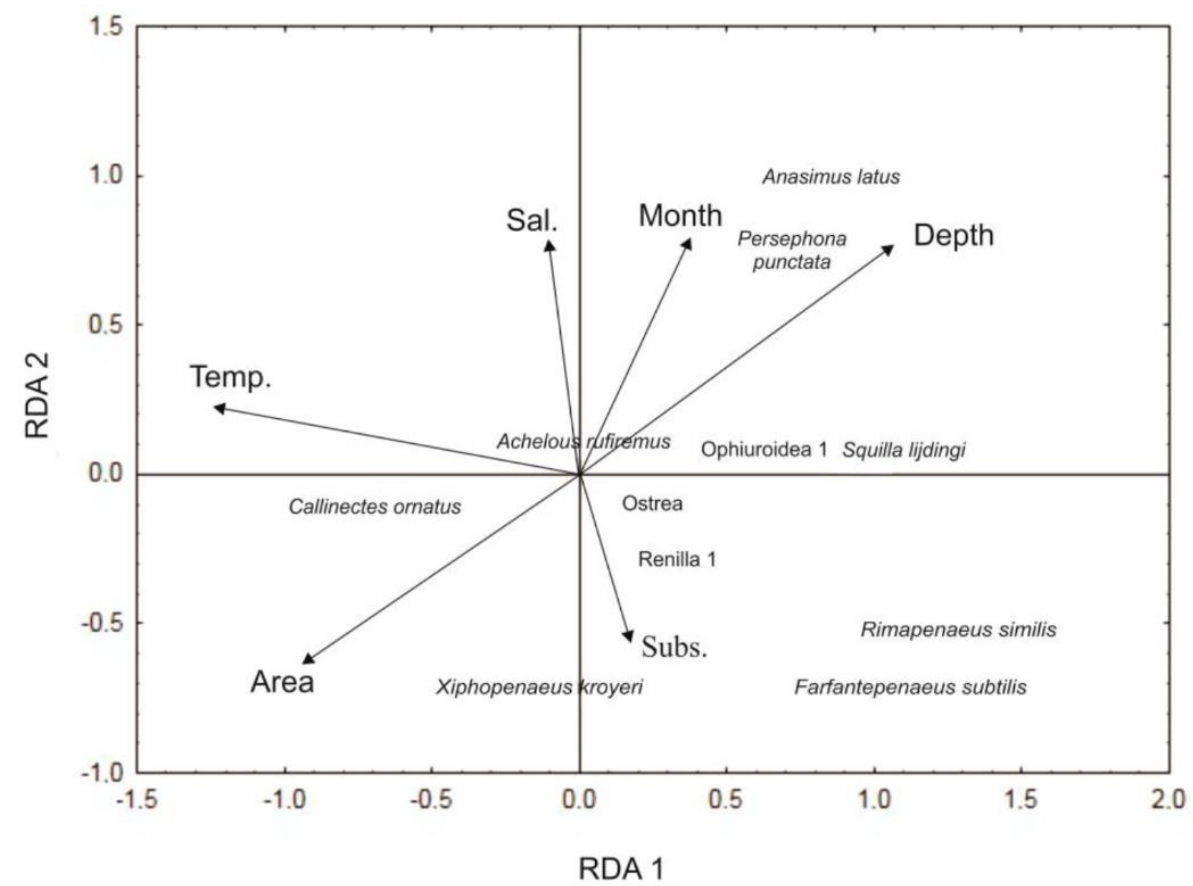

Figure 6. Ordination plot produced by the redundancy analysis (RDA) of the invertebrate bycatch of the shrimp fleet operating on the Amazon continental shelf (July 2015-May 2017). Temp: temperature, Sal: salinity, Subs: subtrate.

provoking differences in temperature, salinity and the penetration of sunlight (Molleri et al. 2010); (iii) the ample spatiotemporal variation in strength of the winds and the North Brazil Current, with the highest values being recorded at $4^{\circ} \mathrm{N}$ during the second half of the year (Geyer et al. 1996), with a fundamental influence on the fixation of benthos; and (iv) the mosaic of sediments, which shifts between south and north, with the southern portion being covered with mottled mud interspersed with sand, and the northern portion being characterized by both these types of sediment, as well as more consolidated and integrated beds of mud (Nittrouer et al. 1986).

Complex environments have various habitats, which can accommodate a greater diversity of life modes than homogeneous environments. The greater concentration of sponges in the southern portion of the continental shelf, and the construction of coral reefs in some specific areas, for example, reflect the environmental complexity (Moura et al. 2016). They are also reflected in the resilience of the Amazonian invertebrate assemblages, which is derived from the different types of control on their diversity, with the southern portion being regulated primarily by biological relationships such as competition and predation, and the northern portion, more by the influence of physical and chemical factors, like turbidity and the penetration of sunlight (Moura et al. 2016).

A few common species' predominances are typical of tropical regions' bycatch (Stobutzki et al. 2001). Two principal factors may account for this model: i) differences in capturability related to factors such as body size and morphology, given that the trawls do not 
Table 5. Results of the canonical correlation analysis between the mean environmental variables and invertebrate densities on the Amazon continental shelf. Values in bold type were considered significant with a confidence limit of $95 \%$.

\begin{tabular}{lcc}
\hline Variable & Axis 1 & Axis 2 \\
\hline Month & 0.27 & 0.52 \\
Area & $\mathbf{- 0 . 7 6}$ & -0.44 \\
Depth & 0.67 & 0.51 \\
Temperature & $\mathbf{- 0 . 8 9}$ & 0.18 \\
Salinity & -0.03 & 0.52 \\
Substrate & 0.12 & -0.39 \\
\hline
\end{tabular}

sample all species with the same efficiency, and ii) distinct levels of vulnerability, which depend on the support capacity and the resilience of each species in response to the disturbances caused by fisheries (Philippart 1998).

The survival rate of a species will depend on its response to different aspects of the stress provoked by the capture process, including exposure to air, plasticity to changes in temperature, sunlight, and the capacity of the animal to recuperate from the physical damage caused by its contact with the trawl (Broadhurst \& Uhlmann 2007). Characteristics such as life-history traits, body size, reproduction, and growth rates also influence these animals' vulnerability to fisheries (Tillin et al. 2006). The crustaceans were dominant in terms of both the number of individuals and species, probably because they are more tolerant to handling, storage, and transport because most species have a rigid exoskeleton, autotomy of the members, and the ability to breathe air, which all favor their survival in comparison with other invertebrates (Hill \& Wassenberg 1990).

Survival rates in crustaceans may vary considerably, even among the same genus species (Hill \& Wassenberg 1990, Moreira et al. 2011, Jimenes et al. 2016), in particular, because the forms that have spiny exoskeletons are more vulnerable to damage (Bergmann et al. 2001). The greater resilience of crustaceans in comparison with other invertebrates does not necessarily imply that fishing pressure does not affect their reproductive success given that, in addition to physical lesions, the behavior of some species, including mating rituals and parental care, is interrupted (Smith 1992). The present study registered the largest number of crustacean species (68) ever recorded in the region, given that Cintra et al. (2017) recorded 44 species in the region, while Cutrim et al. (2001) identified 23 species in the shrimping ground known as "Lixeira" $\left(0^{\circ} 00^{\prime}-1^{\circ} 30^{\prime} \mathrm{N}, 46^{\circ} 50^{\prime}-48^{\circ} 00^{\prime} \mathrm{W}\right)$.
Table 6. The permutational ANOVA of the canonical redundancy analysis model between the environmental variables and the invertebrate assemblage of the Amazon continental shelf (July 2015 through May 2017). Number of permutations: 999. df; degrees of freedom, F: F-ratio, *Significant values $(P<0.05)$.

\begin{tabular}{lcccc}
\hline & df & Variation & F & $P$ \\
\hline Model & 6 & 4.22 & 5.54 & $0.001^{*}$ \\
Residual & 77 & 9.77 & & \\
\hline
\end{tabular}

Achelous rufiremus was the most abundant and widely-distributed species, which indicates that it is well adapted to conditions in the study area, probably because it is not correlated (that is, limited by) any of the abiotic factors analyzed in the present study, which indicates that it is tolerant of the spatiotemporal variation intrinsic to the environment. Despite its reproductive success and apparent lack of threats from human activities, given its absence from national conservation databases (Pinheiro 2016), A. rufiremus has a restricted geographic distribution, being found only in the equatorial western Atlantic Ocean, between Guyana and the Brazilian state of Maranhão (Melo 1996), and little is known of its biology.

Five species, three of shrimp (Rimapenaeus similis, Xiphopenaeus kroyeri, and Farfantepenaeus subtilis) and two of portunid crabs (A. rufiremus and Callinectes ornatus), contributed more than half $(66.70 \%$ of the individuals) of all the bycatch. In general, portunids are predators (Mantelatto \& Christofoletti 2001, Reigada \& Negreiros-Fransozo 2001, Silva et al. 2017), while shrimp are detritivores and omnivores (Willems et al. 2016), and both are highly generalist (Eddy et al. 2017). These species' predominance is consistent with the paradigm of generalists' dominance in disturbed environments (Ramsay et al. 1998). This guild is favored by its ability to adjust its behavior in response to the abrupt physical and biological shifts caused by human activities (Tillin et al. 2006). Also, the physical destruction or mortality of animals in fishery zones increases feeding resources that benefit predators, particularly some crustaceans, which are sensitive to the chemical signals released by damaged tissue (Zimmer-Faust 1993). The predominance of more generalist species within the study region may mediate the functional deficit caused by fisheries by providing environmental redundancy, which makes the benthic ecosystem more resilient and robust (Darr et al. 2014). The swimming crabs are scavengers. The removal of predators/competitors and the abundance of bycatch available to scavenge is possibly beneficial to $A$. rufiremus. 
The variables sub-region, temperature, and depth had a strong influence on taxonomic richness patterns and the variation in some species' abundance. The increasing richness found to the north towards the Caribbean is a well-known pattern in crustaceans (Boschi 2000), which made up the vast majority of the present study's specimens. The strong influence of temperature indicates that, despite the minor variation and constant thermoclines that are typical of tropical regions, the characteristics of the benthic invertebrates of the ACS are consistent with the well-documented pattern of close association with temperature (Negreiros-Fransozo et al. 1999, Gillooly et al. 2001, Brown et al. 2004). The abundance of the crab $C$. ornatus was the most closely correlated with temperature, consistent with several studies in Brazil's subtropical regions (Andrade et al. 2013, Watanabe et al. 2014). The abundance of the target species, $F$. subtilis, is also inversely proportional to temperature (Martins et al. 2015). This systematic association implies that monitoring fluctuations in temperature can offer a practical means of predicting possible biological change scenarios in any study system.

As a purely spatial factor, depth cannot in itself explain patterns of biological richness, although the factors that vary with depth, such as the temperature, salinity, and turbidity of the water, and the sediment load, do control the distribution and abundance of aquatic organisms (McArthur et al. 2010). Given the highly variable sedimentation rates found within the Amazon estuary, the continental shelf is composed of coarser, heterogeneous sediments, and more fluid mud, which is stratified in the shallower parts, that is, at depths of less than $60 \mathrm{~m}$ (Nittrouer et al. 1986), creating areas with a considerable energetic input (Rufino et al. 2006). These conditions are favorable to the excavator life mode of many benthic invertebrates, whose morphology and life-history traits are adapted for the modification of this type of environment, including the creation of micro-habitats and foraging substrates (Pereira et al. 2014), which would account for the decrease in taxonomic richness with increasing depth. However, as the collection of samples in the present study was not based on a systematic ecological research design, it is impossible to confirm these conclusions empirically, given that the vast majority of trawls were undertaken at depths of less than $60 \mathrm{~m}$.

The greater taxonomic richness recorded at the new moon may be related to greater invertebrates capturability during this lunar phase, given that polychaetes and crustaceans, for example, take advantage of the darkness to forage at the surface of the benthic layer (while otherwise mostly remaining buried in the substrate to avoid predation), when they are more easily trapped by trawl nets (Libini \& Khan 2012). The lunar cycle also provides a reliable reference for the species' reproductive behavior synchronization. It confers several advantages, such as reducing predation pressure, given the limits on the number of prey a predator can capture per unit of time (Skov et al. 2005). The new moon also provokes higher tides, which optimize the larvae's dispersal potential (Morgan 1996) and the species' migration, including $F$. subtilis (Aragão et al. 2015).

Overall, then, the invertebrates of the ACS are extremely abundant and characterized by their considerable taxonomic and functional plurality. They play a fundamental role in structuring this environment and are thus essential for developing management strategies based systematically on the relationship between biodiversity and ecosystem function. The spatiotemporal variation in this fauna should be considered in the development of any monitoring program, given that a focus on a single area or taxon will not capture the full biological complexity of the study environment. The most abundant species are generalists, and their greater abundance facilitates monitoring, which favors their adoption as biological indicators. However, it will also be necessary to investigate in more detail the functional roles of the more sensitive and specialist species identified in the present study, given that they are likely to be the most vulnerable to the processes of extinction and loss of ecological function.

\section{ACKNOWLEDGMENTS}

We thank our colleagues Romão Jr., Mairink, and Wagner for their fieldwork of collecting samples. We also appreciate the valuable suggestions of Dr. Bianca Bentes da Silva, Dr. Jonathan Stuart Ready, Dr. Luis Felipe Cestari Dumont, and Dr. Marcelo Petracco, that improved the paper, and Miguel Petrere Jr., David Butturi Gomes, and Eduardo Paes for the help in statistics. To the researchers who kindly contributed to the identification of several taxonomic groups: Prof. Luiz Ricardo Lopes de Simone (mollusks), Prof. Eduardo Martinelli (jellyfish), Prof. Ulisses Pinheiro (Porifera), M.Sc. Thuareag Santos (polychaetes) and Jonathan Ready (cephalopods). To meteorologist Maurício Moura for help with environmental data. This study is part of the Ph.D. thesis of the author (PSVN) and funded by the Brazilian National Research Council (CNPq) through Victoria Isaac, who coordinates the SHRIMP_NEN Project (grant 22/2015). The Center for Research and Management of Fishing Resources of the North Coast (CEPNOR/ICMBio), especially the coordinator Alex Garcia Cavalleiro de Macedo 
Klautau, for collecting and logistic support. We also thank PROPESP/FADESP (PAPQ Program) for sponsoring the translation of the original manuscript by Stephen Ferrari. All experiments conducted in this study complied with current Brazilian federal legislation.

\section{REFERENCES}

Andrade, L.S., Bertini, G., Fransozo, V., Teixeira, G.M., Barros-Alves, S.P. \& Fransozo, A. 2013. Differential occupation of habitat as a reproductive strategy of the blue crab Callinectes ornatus Ordway, 1968 (Crustacea: Decapoda). Marine Biodiversity, 44: 2736. doi: 10.1007/s12526-013-0179-y

Aragão, J.A.N., Silva, K.C.A. \& Cintra, I.H.A. 2015. Situação da pesca de camarões na plataforma continental amazônica. Acta of Fisheries and Aquatic Resources, 3: 61-76.

Bergmann, M., Beare, D.J. \& Moore, P.G. 2001. Damage sustained by epibenthic invertebrates discarded in the Nephrops fishery of the Clyde Sea area, Scotland. Journal of Sea Research, 45: 105-118.

Boschi, E.E. 2000. Species of decapod crustaceans and their distribution in the American marine zoogeographic provinces. Revista de Investigación y Desarrollo, 13: 7-136.

Broadhurst, M.K. \& Uhlmann, S.S. 2007. Short-term stress and mortality of juvenile school prawns, Metapenaeus macleayi, discarded from seines and trawls. Fisheries Management and Ecology, 14: 353363.

Brown, J.H., Gillooly, J.F., Allen, A.P., Savage, V.M. \& West, G.B. 2004. Toward metabolism as ecological theory. Ecology, 85: 1771-1789.

Buhl-Mortensen, L., Ellingsen, K.E., Buhl-Mortensen, P., Skaar, K.L. \& Gonzalez-Mirelis, G. 2016. Trawling disturbance on megabenthos and sediment in the Barents Sea: chronic effects on density, diversity, and composition. ICES Journal of Marine Science, 73: 98114.

Cintra, I.R.A., Paiva, K.S., Herrmann, M., Barbosa, J.M., Klautau, A.G.M. \& Silva, K.C.A. 2017. Carcinofauna acompanhante do camarão-rosa em pescarias industriais na plataforma continental amazônica. Acta of Fisheries and Aquatic Resources, 5: 83-91.

Cutrim, R.S.F., Silva K.C. \& Cintra, I.R.A. 2001. Composição dos recursos pesqueiros capturados na área da "Lixeira", Pará, Brasil. Boletim TécnicoCientífico do CEPNOR, 1: 59-76.

Darr, A., Gogina, M. \& Zettler, M.L. 2014. Functional changes in benthic communities along a salinity gradient - a western Baltic case study. Journal of Sea Research, 85: 315-324. doi: 10.1016/j.seares.2013. 06.003

Eddy, T.D., Lotze, H.K., Fulton, E.A., Coll, M., Ainsworth, C.H., Araújo, J.N., et al. 2017. Ecosystem effects of invertebrate fisheries. Fish and Fisheries, 18: 40-53. doi: 10.1111/faf.12165

Flack, V.F. \& Flores, R.A. 1989. Using simulated envelopes in the evaluation of normal probability plots of regression residuals. Technometrics, 31: 219-225.

Frid, C.L.J., Harwood, K.G., Hall, S.J. \& Hall, J.A. 2000. Long-term changes in the benthic communities on North Sea fishing grounds. ICES Journal of Marine Science, 57: 1303-1309. doi: 10.1006/jmsc.2000.0900

Fulton, E.A., Smith, A.D.M. \& Punt, A.E. 2005. Which ecological indicators can robustly detect effects of fishing? ICES Journal of Marine Science, 62: 540-551. doi: 10.1016/j.icesjms.2004.12.012

Geyer, R.W., Beardsley, R.C., Lentz, S.J., Candela, J., Limeburner, R., Johns, W.E., et al. 1996. Physical oceanography of the Amazon shelf. Continental Shelf Research, 16: 575-616.

Gillooly, J.F., Brown, J.H., West, G.B., Savage, V.M. \& Charnov, E.L. 2001. Effects of size and temperature on metabolic rate. Science, 293: 2248-2251. doi: 10.1126/ science. 1061967

Graça-Lopes, R., Severino-Rodrigues, E., Puzzi, A., Pita, J.B., Coelho, J.A.P. \& Freitas, M.L. 1993. Levantamento ictiofaunístico em um ponto fixo na baía de Santos, Estado de São Paulo, Brasil. Boletim do Instituto de Pesca, 20: 7-20.

Guerra, A., González, A.F., Earl, S.P. \& Dawe, G. 2011. The giant squid Architeuthis: an emblematic invertebrate that can represent concern for the conservation of marine biodiversity. Biological Conservation, 144: 989-1997.

Hall, M.A., Alverson, D.L. \& Metuzals, K.I. 2000. Bycatch: problems and solutions. Marine Pollution Bulletin, 41: 204-219. doi: 10.1016/S0025-326X(00) 00111-9

Harley, C.D.G., Hughes, A.R., Hultgren, K.M., Miner, B.G., Sorte, C.J.B., Thornber, C.S., et al. 2006. The impacts of climate change in coastal marine systems. Ecology Letters, 9: 228-241. doi: 10.1111/j.14610248.2005.00871.x

Hill, B.J. \& Wassenberg, T.J. 1990. Fate of discards from prawn trawlers in Torres Strait. Australian Journal of Marine and Freshwater Research, 41: 53-64.

Hothorn, T., Bretz, F. \& Westfall, P. 2008. Simultaneous inference in general parametric models. Biometrical Journal, 50: 346-363. 
Hinde, J. \& Demétrio, C.G.B. 1998 Overdispersion: models and estimation. Computational Statistics \& Data Analysis, 27: 151-170.

Jimenez, H., Pascal, D., Mouillot, D., Bigot, L. \& Ferraris, J. 2016. Harvesting effects on functional structure and composition of tropical invertebrate assemblages. ICES Journal of Marine Science, 73: 420-428.

Legendre, P. 2008. Studying beta diversity: ecological variation partitioning by multiple regression and canonical analysis. Journal of Plant Ecology, 1: 3-8. doi: 10.1093/jpe/rtm001

Libini, C. \& Khan, S. 2012. Influence of lunar phases on fish landings by gillnetters and trawlers. Indian Journal of Fisheries, 59: 81-87.

Mantelatto, F.L.M. \& Christofoletti, R.A. 2001. Natural feeding activity of the crab Callinectes ornatus (Portunidae) in Ubatuba Bay (São Paulo, Brazil): influence of season, sex, size and molt stage. Marine Biology, 138: 585-594. doi: 10.1007/s002270000474

Martins, D.E.G., Zorro, M.C., Souza Filho, P.W., Cintra, I.H.A. \& Silva, K.C.A. 2015. Spatial distribution of southern brown shrimp (Farfantepenaeus subtilis) on the Amazon continental shelf: a fishery, marine geology and GIS integrated approach. Brazilian Journal of Oceanography, 63: 83-92.

Masson, S. \& Delecluse, P. 2001. Influence of the Amazon River runoff on the tropical Atlantic. Physics and Chemistry of the Earth - Part B: Hydrology Oceans and Atmosphere, 26: 137-142.

McArthur, M.A., Brooke, B.P., Przeslawski, R., Ryan, D.A., Lucieer, V.L., Nichol, S., et al. 2010. On the use of abiotic surrogates to describe marine benthic biodiversity. Estuarine and Coast Shelf Science, 88: 21-32. doi: 10.1016/j.ecss.2010.03.003

McCullagh, P. \& Nelder, J.A. 1989. Generalized linear models. Chapman and Hall, London.

Melo, G.A.S. 1996. Manual de identificação dos Brachyura (caranguejos e siris) do litoral brasileiro. Plêiade, São Paulo. 603 pp.

Molleri, G.S.F., Novo, E.M.L.M. \& Kampel, M. 2010. Space-time variability of the Amazon River plume based on satellite ocean color. Continental Shelf Research, 30: 342-352. doi: 10.1016/j.csr.2009.11.015

Moral, R.A, Hinde, J. \& Demétrio, C. 2017. Half-normal plots and overdispersed models in R: the hnp package. Journal of Statistical Software, 81: 1-23.

Moreira, F.N., Vianna, M., Lavrado, H.P., Silva-Junior, D.R. \& Keunecke, K.A. 2011. Survival and physical damage in swimming crabs (Brachyura, Portunidae) discarded from trawling fisheries in an estuarine ecosystem in southeastern Brazil. Crustaceana, 84: 1295-1306. doi: 10.1163/156854011X596937
Morgan, S.G. 1996. Plasticity in reproductive timing by crabs in adjacent tidal regimes. Marine Ecology Progress Series, 39: 105-118.

Moura, R.L., Amado-Filho, G.M., Moraes, F.C., Brasileiro, P.S., Salomon, P.S., Mahiques, M.M., et al. 2016. An extensive reef system at the Amazon River mouth - supplementary material. Science Advances, 2: e1501252. doi: 10.1126/sciadv. 1501252

Negreiros-Fransozo, M.L., Mantelatto, F.L.M. \& Fransozo, A. 1999. Population biology of Callinectes ornatus Ordway, 1863 (Decapoda, Portunidae) from Ubatuba (SP), Brazil. Scientia Marina, 63: 157-163.

Nittrouer, C.A., Kuehl, S., Demaster, D.J. \& Kowsmann, R.O. 1986. The deltaic nature of Amazon shelf sedimentation. Bulletin of the Geological Society of America, 97: 444-458.

Pereira, R.T., Teixeira, G.M., Bertini, G., Lima, P.A., Alencar, C.E.R.D. \& Fransozo, V. 2014. Environmental factors influencing the distribution of three species within the genus Persephona Leach, 1817 (Crustacea, Decapoda, Leucosiidae) in two regions on the northern coast of São Paulo State, Brazil. Latin American Journal of Aquatic Research, 42: 307-321. doi: 10.3856/vol42-issue2-fulltext-3

Philippart, C.J.M. 1998. Long-term impact of bottom fisheries on several bycatch species of demersal fish and benthic invertebrates in the southeastern north. Sea. ICES Journal of Marine Science, 55: 342-352. doi: 10.1006/jmsc. 1997.0321

Pinheiro, M.A.A., Boos, H., Reigada, A.L.D., Rodrigues, E.S., Rocha, S.S., Hereman, M.J. \& Souza, M.R. 2016. Avaliação dos caranguejos portunídeos (Decapoda: Portunoidea: Ovalipidae, Polybiidae e Portunidae). In: Pinheiro, M.A.A. \& Boos, H. (Eds.). Livro vermelho dos crustáceos do Brasil. Avaliação 2010-2014. Sociedade Brasileira de Carcinologia, Porto Alegre.

R Core Team. 2017. R: a language and environment for statistical computing. R Foundation for Statistical Computing. [http://www.R-project.org]. Reviewed: April 8, 2020.

Ramsay, K., Kaiser, M.J. \& Hughes, R.N. 1998. Responses of benthic scavengers to fishing disturbance by towed gears in different habitats. Journal of Experimental Marine Biology and Ecology, 224: 7389. doi: 10.1016/S0022-0981(97)00170-6

Reigada, A.L.D. \& Negreiros-Fransozo, M.L. 2001. Feeding activity of Callinectes ornatus Ordway, 1863 and Callinectes danae Smith, 1869 (Crustacea, Brachyura, Portunidae) in Ubatuba, SP, Brazil. Hydrobiologia, 449: 249-252.

Rufino, M.M., Maynou, F., Abelló, P. \& Sardá, F. 2006. Spatial and environmental factors affecting the distribution of the main decapod crustacean prey 
species in the NW Mediterranean. Hydrobiologia, 555: 129-141. doi: 10.1007/s10750-005-1111-7

Silva, T.E., Taddei, F.G., Bertini, G., Andrade, L.S., Teixeira, G.M. \& Fransozo, A. 2017. Population structure of the swimming crab Achelous spinicarpus (Crustacea, Portunoidea) in São Paulo northern coast, Brazil. Neotropical Biology and Conservation, 12: 164-170. doi: 10.4013/nbc.2017.123.01

Skov, M.W., Hartnoll, R.G., Ruwa, R.K., Shunula, J.P., Vannini, M. \& Cannicci, S. 2005. Marching to a different drummer: crabs synchronize reproduction to a 14-month lunar-tidal cycle. Ecology, 86: 1164-1171. doi: 10.1890/04-0917

Smith, L.D. 1992. The impact of limb autotomy on mate competition in blue crabs Callinectes sapidus Rathbun. Oecologia, 89: 494-501.

Stobuzki, I., Miller, M., Jones, P. \& Salini, P. 2001. Bycatch diversity and variation in a tropical Australian penaeid fishery, the implications for monitoring. Fisheries Research, 53: 283-301.

Tillin, H.M., Hiddink, J.G., Jennings, S. \& Kaiser, M.J. 2006. Chronic bottom trawling alters the functional composition of benthic invertebrate communities on a sea-basin scale. Marine Ecology Progress Series, 318: 31-45. doi: 10.3354/meps318031

Tonks, M.L., Griffiths, S.P., Heales, D.S., Brewer, D.T. \& Dell, Q. 2008. Species composition and temporal variation of prawn trawl bycatch in the Joseph Bonaparte Gulf, northwestern Australia. Fisheries Research, 89: 276-293. doi: 10.1016/j.fishres.2007. 09.007

Received: 8 July 2020; Accepted: 7 October 2020
Vale, N.F., Amado-Filho, G.M., Braga, J.C., Brasileiro, P.S., Karez, C.S., Moraes, F.C., et al. 2018. Structure and composition of rhodoliths from the Amazon River mouth, Brazil. Journal of South American Earth Sciences, 84: 149-159. doi: 10.1016/j.jsames.2018. 03.014

Venables, W.N. \& Ripley, B.D. 2002. Modern applied statistics with S. Springer, Berlin.

Watanabe, T.T., Sant'Anna, B.S., Hattori, G.Y. \& Zara, F.J. 2014. Population biology and distribution of the portunid crab Callinectes ornatus (Decapoda: Brachyura) in an estuary-bay complex of southern Brazil. Zoologia, 31: 329-336. doi: 10.1590/S198446702014000400004

Willems, T., De Backer, A., Kerkhove, T., Dakriet, N.N., De Troch, M., Vincx, M. \& Hostens, K. 2016. Trophic ecology of Atlantic seabob shrimp Xiphopenaeus kroyeri: interdal benthic microalgae support the subtidal food web off Suriname. Estuarine, Coastal and Shelf Science, 182: 146-157.

Zeller, D. \& Pauly, D. 2005. Good news, bad news: global fisheries discards are declining, but so are total catches. Fish and Fisheries, 6: 156-159. doi: 10.1111/ j.1467-2979.2005.00177.x

Zimmer-Faust, R.K. 1993. ATP: a potent prey attractant evoking carnivory. Limnology and Oceanography, 38: 1271-1275. 